\title{
TRAINING REQUIREMENTS AND RESPONSIBILITIES FOR THE BURIED WASTE INTEGRATED DEMONSTRATION AT THE RADIOACTIVE WASTE MANAGEMENT COMPLEX
}

Published September 1992

Idaho National Engineering Laboratory

EG\&G Idaho, Inc.

Idaho Falls, Idaho 83415

Prepared for the

U.S. Department of Energy

Office of Environmental Restoration and Waste Management

Under DOE Idaho Field Office

Contract DE-AC07-76ID01570 
Training Requirements and Responsibilities for the Buried Waste Integrated Demonstration at the Radioactive Waste Management Complex

EGG-WTD-10400

Approved by:

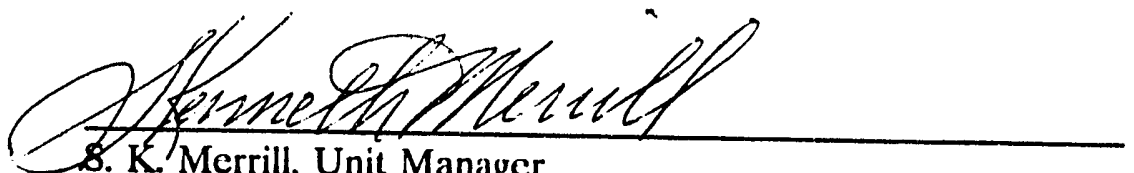

Environmental Restoration Technical Department Programs

Concurrence by:

$\frac{\text { J.R. Bishoff (eating) / L.R.Pration per telecon }}{\text { D. L. French, Facility Manager }}$ RWMC/SWEPP Programs

Reviewed by:

D.S.Bright/L.R. D) Tatar per telecon Technical Programs

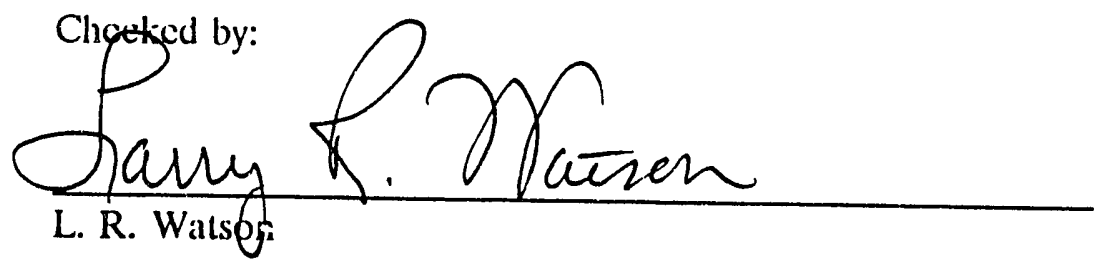

Prepared by:

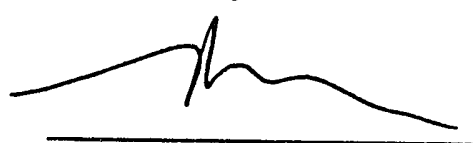

H. G. Vega
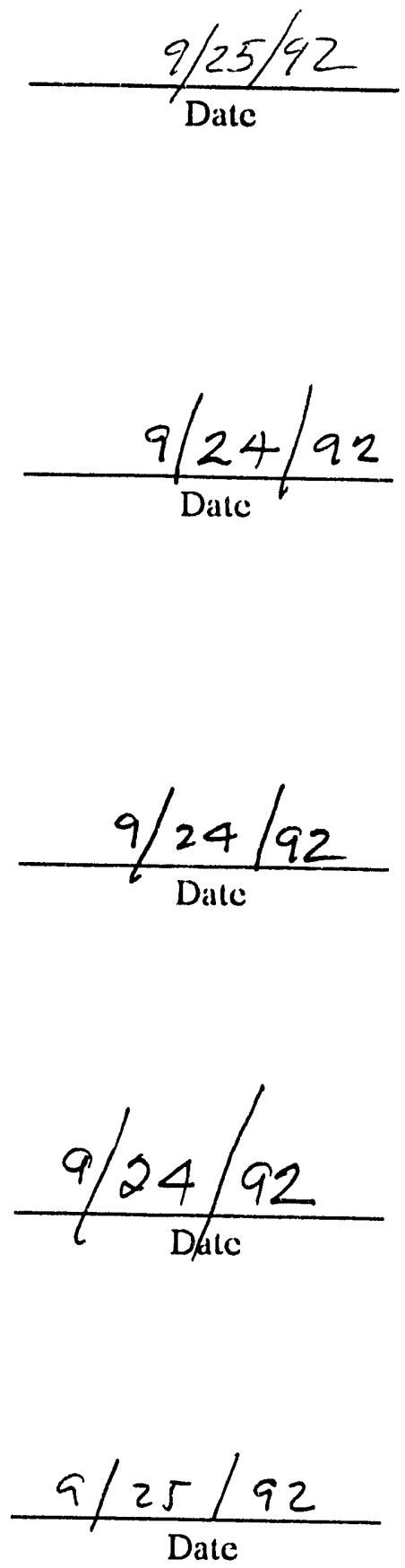


\begin{abstract}
The Buried Waste Integrated Demonstration (BWID) is scheduled to conduct intrusive (hydropunch screening tests, bore hole installation, soil sampling, etc.) and nonintrusive (geophysical surveys) studies at the Radioactive Waste Management Complex (RWMC). These studies and activities will be limited to specific locations at the RWMC. The duration of these activities will vary, but most tasks are not expected to exceed 90 days. The BWID personnel requested that the Waste Management Operational Support Group establish the training requirements and training responsibilities for BWID personnel and BWID subcontractor personnel. This document specifies these training requirements and responsibilities. While the responsibilities of BWID and the RWMC are, in general, defined in the interface agreement, the training elements are based on regulatory requirements, DOE orders, DOE-ID guidance, state law, and the nature of the work to be performed.
\end{abstract}




\section{CONTENTS}

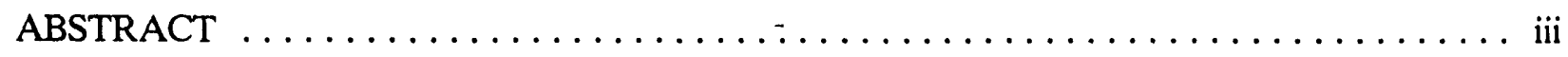

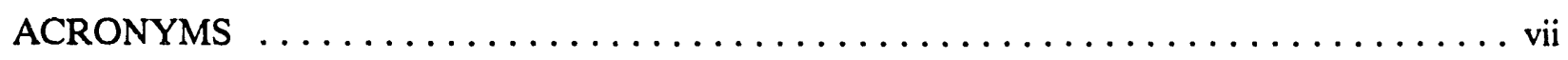

1. INTRODUCTION AND BACKGROUND $\ldots \ldots \ldots \ldots \ldots \ldots \ldots \ldots \ldots \ldots$

1.1 Introduction $\ldots \ldots \ldots \ldots \ldots \ldots \ldots \ldots \ldots \ldots \ldots \ldots \ldots \ldots \ldots \ldots \ldots \ldots \ldots, 1$

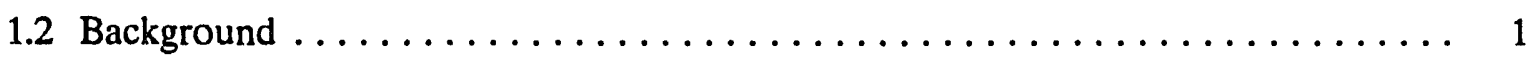

1.3 Training Organizational Relationship $\ldots \ldots \ldots \ldots \ldots \ldots \ldots \ldots \ldots \ldots, 2$

2. TRAINING AND RESPONSIBILITY PLAN OBJECTIVES $\ldots \ldots \ldots \ldots \ldots \ldots \ldots 4$

3. FACILITY DESCRIPTION $\ldots \ldots \ldots \ldots \ldots \ldots \ldots \ldots \ldots \ldots \ldots \ldots \ldots \ldots \ldots \ldots$

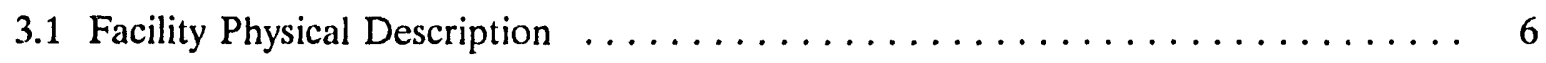

4. TRAINING RESPONSIBILITIES $\ldots \ldots \ldots \ldots \ldots \ldots \ldots \ldots \ldots \ldots \ldots \ldots \ldots \ldots \ldots \ldots \ldots$

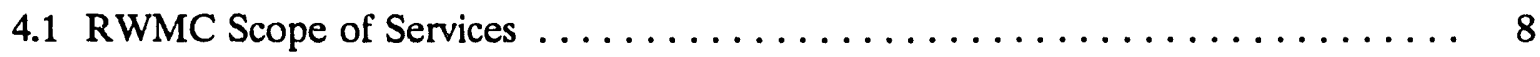

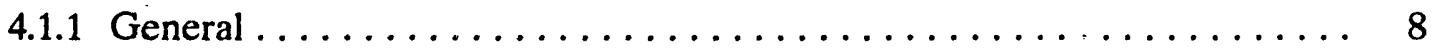

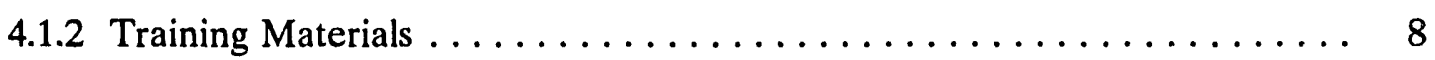

4.1.3 RWMC Access Orientation Training $\ldots \ldots \ldots \ldots \ldots \ldots \ldots \ldots \ldots, 9$

4.1.4 Documentation ............................. 10

4.2 BWID and BWID Subcontractor Training Responsibilities $\ldots \ldots \ldots \ldots \ldots \ldots 11$

4.2.1 General .................................. 11

4.2.2 Health and Safety Plan Addendum $\ldots \ldots \ldots \ldots \ldots \ldots \ldots \ldots \ldots \ldots \ldots$

4.2.3 Determination of Specific BWID Safety Training $\ldots \ldots \ldots \ldots \ldots \ldots \ldots$

4.2.4 Mandatory Training Requirements $\ldots \ldots \ldots \ldots \ldots \ldots \ldots \ldots \ldots \ldots \ldots \ldots$

5. TRAINING IMPLEMENTATION STRUCTURE $\ldots \ldots \ldots \ldots \ldots \ldots \ldots \ldots \ldots \ldots$

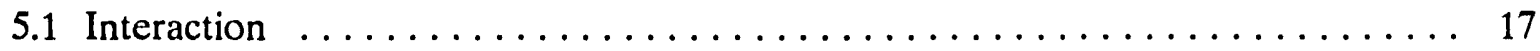




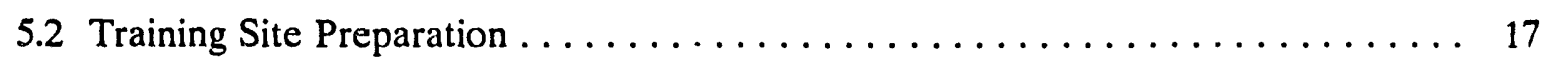

5.2.1 Preliminary Documentation $\ldots \ldots \ldots \ldots \ldots \ldots \ldots \ldots \ldots \ldots \ldots \ldots \ldots \ldots \ldots$

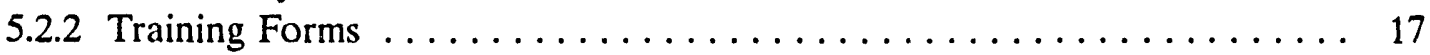

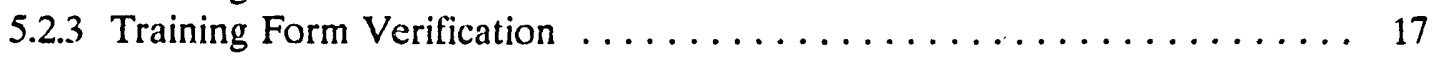

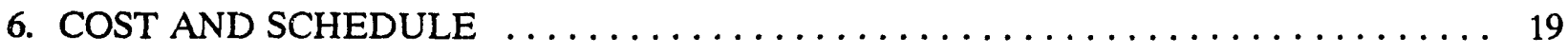

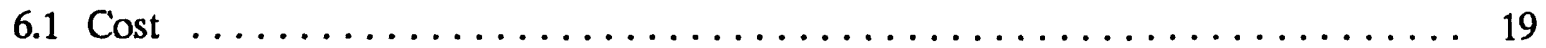

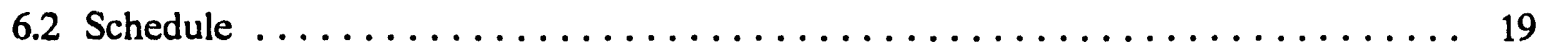

7. QUALITY ASSURANCE PROGRAM $\ldots \ldots \ldots \ldots \ldots \ldots \ldots \ldots \ldots \ldots \ldots$

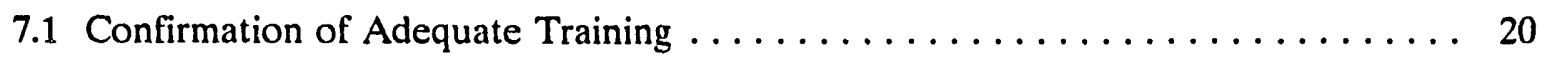

7.2 Training Management and Verification During Technology Demonstration $\ldots . \ldots 21$

7.3 Quality Control and Evaluation $\ldots \ldots \ldots \ldots \ldots \ldots \ldots \ldots \ldots \ldots \ldots \ldots \ldots \ldots \ldots$

7.4 Document and Configuration Control $\ldots \ldots \ldots \ldots \ldots \ldots \ldots \ldots \ldots \ldots \ldots \ldots$

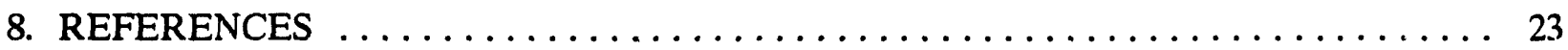

ATTACHMENT 1 - BURIED WASTE INTEGRATED DEMONSTRATION OPERATIONAL

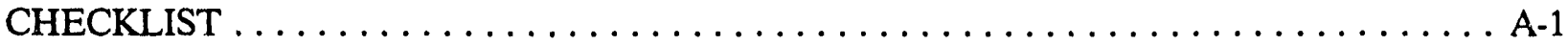

ATTACHMENT 2 - TRAINING PLAN MATRIX $\ldots \ldots \ldots \ldots \ldots \ldots \ldots \ldots$ B-1

\section{FIGURE}

1. Radioactive Waste Management Complex $\ldots \ldots \ldots \ldots \ldots \ldots \ldots \ldots \ldots \ldots$

\section{TABLES}

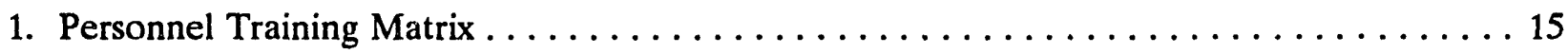

2. 29 CFR 1910.120 -- Hazardous Waste Operations

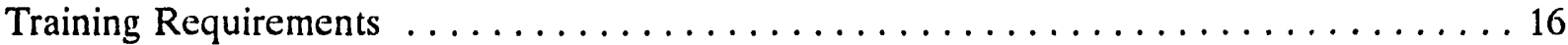




\section{ACRONYMS}

BWID Buried Waste Integrated Demonstration

C\&S Certified and Segregated

CERCLA Comprehensive Environmental Response, Compensation, and Liability Act

CFA Central Facilities Area

CFR Code of Federal Regulations

COCA Consent Order Compliance Agreement

D\&D Decontamination \& Decommissioning

DCAM Deployment Cost Account manager

DOE Department of Energy

DOE-ID DOE Idaho Field Office

ERP Environmental Restoration Programs

ERS Environmental Restoration Sites

FERA Facility Emergency Responder Action

HSP Health and Safety Plan

HW Hazard Waste

INEL Idaho National Engineering Laboratory

OSHA Occupational Safety and Health Administration

OSR Operational Safety Requirements

PPE Personal Protective Equipment

RCRA Resource Conservation and Recovery Act

RWMC Radioactive Waste Management Complex

SAR Safety Analysis Report

SDA Subsurface Disposal Area

SWEPP Stored Waste Examination Pilot Plant

T\&EA Training and Emergency Action

TRRP Training and Responsibility Plan

TRU Transuranic

TSA Transuranic Storage Area

TSD Treatment Storage Disposal

TSR Technical Safety Requirement

WMF Waste Management Facility 


\section{TRAINING REQUIREMENTS AND RESPONSIBILITIES FOR THE PERFORMANCE OF THE BURIED WASTE INTEGRATED DEMONSTRATION AT THE RADIOACTIVE WASTE MANAGEMENT COMPLEX}

\section{INTRODUCTION AND BACKGROUND}

\subsection{Introduction}

This plan defines the minirnum training requirements, and the responsibilities of the parties involved in the training, that are necessary to comply with RWMC and associated administrative operational controls for work performed at the RWMC. In addition, this TRRP will be used to ensure that the quality of training provided to BWID personnel and BWID subcontractor personnel meets regulatory standards for reporting and demonstrating compliance, and meets general facility training requirements. Where appropriate, this document may be utilized for general guidance by BWID Technology demonstrations performed at other facilities.

\subsection{Background}

The Environmental Restoration Program (ERP) conducts several programs at the INEL, including the Buried Waste Program, the Consent Order Compliance Agreement Program, and the Decontamination and Decommissioning Program. The Buried Waste Integration Demonstration (BWID) Program is a part of the EG\&G Idaho Environmental Restoration Technical Development Program Unit and is responsible for managing and coordinating BWID functional activities at facilities throughout the INEL. The BWID Program is responsible for overseeing all phases of the technology demonstration testing, satisfying and completıng applicable training requirements to operate at the RWMC, and supervising and directing the activities of subcontractors. A more complete description of the BWID activities, including some specific tests conducted or proposed to be conducted at the RWMC, can be found in the Interface Agreement Between the Radioactive Waste Management 
Complex Building Manager and Buried Waste Integration Demonstration-Integrated Demonstration Coordinator. ${ }^{1}$

The Deployment Cost Account manager (DCAM) was directed by BWID to coordinate field activities at the RWMC. The DCAM has been tasked to ensure Federal requirements that deal specifically with hazardous waste worker's safety, training, and emergency response requirements are met during the performance of BWID studies or field activities at the RWMC. The BWID embraces several different BWID technology demonstrations; as a result, specific personnel training requirements differ, depending on the type and duration of the demonstration. In contrast, RWMC training requirements remain consistent.

\subsection{Training Organizational Relationship}

The RWMC manager is responsible for developing and approving the various formal training programs or training requirements as identified in interface agreement. This document will ensure that DOE, EG\&G Idaho, waste generator personnel, BWID or BWID subcontractors, and other entities visiting the facility, have completed the appropriate entry, access, and other RWMC-specific training before entry. Personnel that are under a full-time escort while at the facility are the exception.

The BWID Management will ensure that the BWID's or its subcontractor's applicable environmental, health, and safety plans (HSP) meet prescribed safety and health standards for RWMC.

Under the direction of the RWMC manager, the RWMC Training and Emergency Action (T\&EA) training coordinator conducts training activities at the RWMC. These should include developing requirements-based training programs, conducting training, maintaining question and answer banks, preparing tests, and evaluating training results. These training coordinator activities are specific to RWMC operations. 
Under the provisions of the interface agreement, BWID personnel and BWID subcontractor personnel must comply with RWMC training requirements and responsibilities applicable to BWID technology demonstrations specifically training recommended by OSHA (see Attachments 1 and 2). Therefore, the RWMC T\&EA Unit shall be responsible for conducting the RWMC access orientation training and the facility-specific training for RWMC. The training responsibilities section of this TRRP describes in greater detail the applicable training provided by the T\&EA Unit to the BWID personnel.

If required, safety-related training is available from Centralized Safety Training (as defined in the EG\&G Idaho, Inc., Safety Manual ${ }^{2}$ ), located at the Central Facilities Area (CFA). Included in the safety related courses are: ${ }^{a}$

TS-509 Health \& Safety Permit

TS-501 Radiation Worker

TS-801 Respirator

TS-207 24-Hour Hazardous Waste Operations and Emergency Response

TS-205 40-Hour Hazardous Waste Operations and Emergency Response

TS-206 Hazardous Waste Operations and Emergency Response Supervisor

TS-100 General Hazard Communications

A complete list of courses, course fees, and schedule may be obtained from Centralized Safety Training, Point of contact: B. M. Monson, 526-2999, MS-4129.

a. A BWID contractor may be exempted from a training requirement based on prior qualifications or certification. Exemptions listing the justification shall be granted in writing and shall be properly documented. 


\section{TRAINING AND RESPONSIBILITY PLAN OBJECTIVES}

This TRRP specifies the training curriculum and responsibilities that must be addressed by BWID personnel and BWID subcontractor personnel before conducting intrusive or nonintrusive studies or activities at, or adjacent to the RWMC at the Idaho National Engineering Laboratory.

This TRRP addresses current operations and practices that have evolved through field operation experience and established standards at the RWMC. As new field activities are identified, or when RWMC cognizant professionals deem necessary, revisions to fulfill all aspects of the training requirements and BWID responsibilities, this document will be revised by the BWID. Normal practices require that the revision be performed before commencing project operations.

The TRRP shall provide guidance to both the BWID and the RWMC to determine the leve! of responsibility (on the part of both parties) required to ensure all BWID training requirements and training responsibilities are conducted according to the requirements of the interface agreement. All aspects of the training curriculum and responsibilities are necessary to ensure that the work performed by the BWID personnel or BWID subcontractor personnel comply with U. S. Department of Energy and EG\&G Idaho, Inc., requirements.

This IRRP also details RWMC services. The T\&EA staff at the RWMC shall provide the RWMC Access Orientation training, which covers facility-specific training in the following areas:

- Introduction to, and general description of, the RWMC facilities

- RWMC radiological health and safety

- $\quad$ RWMC industrial safety

- RWMC industrial hygiene

- $\quad$ RWMC emergency preparedness

- $\quad$ ravility Emergency Responder Action (FERA)

- RWMC security program.

A complete course outline is provided in Section 4. 
In addition to this training, the BWID Program shall be responsible for providing the specific training in intrusive and nonintrusive studies applicable to the BWID technology demonstration. This includes, but is not limited to:

1. Intrusive studies

- $\quad$ Basic training

- Continuous soil sampling hazards

- Decontamination of drilling and sampling equipment

- Drilling equipment hazards

- Personal protective equipment

- Task Specific Health and Safety Plan or equivalent detailed operating procedure documentation.

2. Nonintrùsive studies

- Task Specific Health and Safety Plan or equivalent detailed operating procedure documentation. 


\section{FACILITY DESCRIPTION}

\subsection{Facility Physical Description}

The Radioactive Waste Management Complex is located on 164.6 acres of land in the southwest area of the Idaho National Engineering Laboratory approximately seven miles from the Central Facilities Area. The primary purpose of the RWMC facility is to dispose of low level waste and to examine, process, and temporarily store transuranic (TRU) radioactive waste. R!VMC, shown in Figure 1, consists of approximately 20 buildings and structures within the boundaries of the INEL.

The RWMC consists of four distinct areas: 1) The administrative area contains four buildings. These buildings house security, engineering and document control personnel and the telephone support system. 2) The operations support area includes seven buildings and structures that house support personnel and a water storage tank; they a service buildings. 3) The Transuranic Storage Area (TSA) consists of eight buildings and structures in which transuranic waste $(>100 \mathrm{nCi} / \mathrm{g})$ is stored and examined and prepared for shipment. The storage facility includes two air support weather shields and the Intermediate Level Transuranic Storage Facility (ILTSF). 4) The Subsurface Disposal Area (SDA) contains pits and soil vaults for disposal of low-level waste ( $<100 \mathrm{nCi} / \mathrm{g}$ of TRU waste).

The RWMC is owned and operated by the DOE Idaho Field Office (DOE-ID). The waste mánagement unit is operated by the Environmental Restoration and Waste Management Department of EG\&G Idaho under the authority of and through contractual arrangement with, DOE-ID. The RWMC Manager is the designated authority managing the facility. A complete description of the RWMC and its current scope of operation can be found in the Operational Safety Requirements for the Radioactive Waste Management Complex. ${ }^{3}$ The BWID technology demonstration will focus on the SDA and to some extent the TSA. 
옹

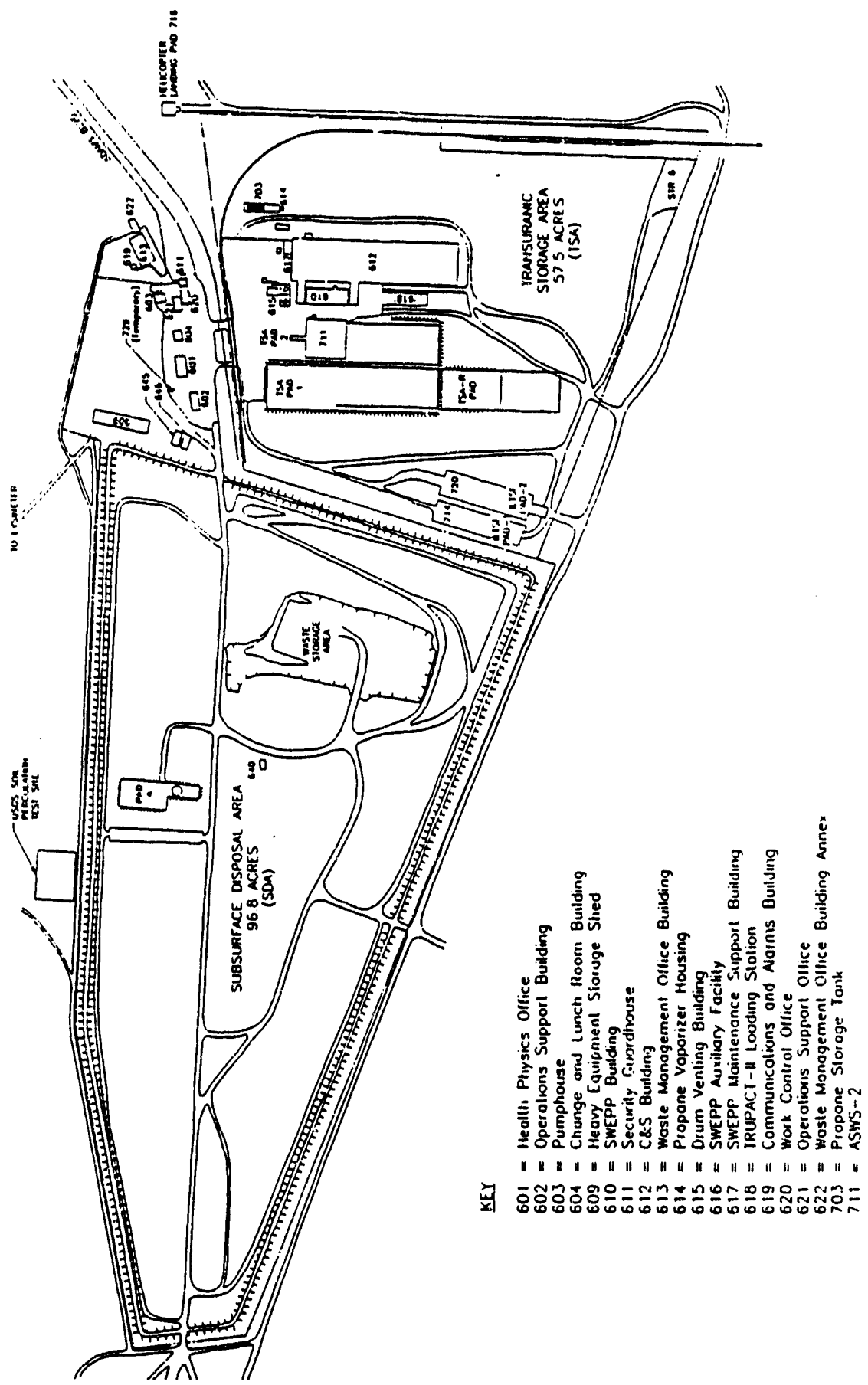

 


\section{TRAINING RESPONSIBILITIES}

To meet the overall training objectives for the BW/ID technology demonstrations, the DCAM will coordinate and combine the efforts of both the Training and Emergency Action Unit staff at the RWMC and the BWID or BWID subcontractor personnel for each specific technology demonstration. To avoid conflicts and schedule delays during the performance of techiology demonstrations or related activity (on the part of both parties), the DCAM shall request the required support services well before they will be needed. Likewise, T\&EA will provide the required training support or information expeditiously. This section identifies the training responsibility of PWID or BWID subcontractor personnel, or both, and the T\&EA staff at RWMC.

\subsection{RWMC Scope of Services}

\subsubsection{General}

The RWMC shall provide adequate space to conduct th . 1acility access orientation training. In addition, equipment and material needed to complete this training shall be provided.

The RWMC shall assign a trainer or a contact person to support this function. This individual will oversee the coordination of the training requirements and training responsibilities for each BWID technology demonstration, administer all instruction relevant to the RWMC training responsibilities and RWMC Access Orientation training, and answer or obtain answers to all questions from or to BWID or BWID subcontractors concerning the RWMC Access Orientation and training responsibilities.

\subsubsection{Training Materials}

Training materials needed to support the RWMC training shall be provided by RWMC, including audiovisual equipment, training aids, and devices (e.g., overhead projectors, videotape player and monitors). 


\subsubsection{RWMC Access Orientation Training}

The RWMC Access Orientation training for the BWID and BWID subcontractor shall include:

1. Introduction and general description of the RWMC facilities

- Introduction

- General description of facility

- $\quad$ Reading direct reading dosimeters

- $\quad$ Facility tour (optional).

2. RWMC radiological health and safety

- Personnel and vehicle access control

- Facility-specific radiation safety briefing

- Radiological monitoring

- Instrumentation and alarms

- $\quad$ Release tags

- Alpha concerns.

3. Industrial safety/Industrial hygiene

- $\quad$ Site-specific hazards briefing

- RCRA/CERCLA briefing

- Health and Safety briefing. 
4. Eimergency preparedness

- $\quad$ Emergency response briefing

- Facility alarms and signals

- $\quad$ Emergency procedures.

5. Security Program

- Verify ID and Health and Safety Permit Card

- Facility security awareness briefing.

6. Unescorted access examination.

The RWMC Training Coordinator will document the completion of the RWMC Access Orientation training for individuals, including the date and training received. The RWMC Access Orientation training course is vased on requirements described in Section 4.2. This course outline may be changed as training requirements change. The level of detail covered in the training topics will be based on the needs of the personnel requiring training. In general, for scheduling purposes, the RWMC Access Orientation will require approximately four hours.

\subsubsection{Documentation}

The RWMC Training Coordinator or instructor shall provide the DCAM copies of class attendance rosters, and other training information deemed necessary by the DCAM. A copy of required training shall be maintained on site for each T\&EA Unit technology demonstration. In addition, when personnel have completed the RWMC Access Orientation their individual Health and Safety Permit cards will be endorsed for RWMC access. This endorsement shall remain in effect for 1 year. Attachment 2 shall be used th. monitor and track the trair ing required of all individuals assigned to a particular BWID project demonstration. 


\subsection{BWID and BWID Subcontractor Training Responsibilities}

\subsubsection{General}

Personnel of BWID and BWID subcontractor shall comply with applicable training requirements and training responsibilities detailed in the EG\&G Idaho, Inc., Safety Manual, ${ }^{2}$ the RWMC Operational Safety Requirement (OSR) Safety Analysis Report, ${ }^{3}$ and the ERP Generic Frealth and Safety Plan. ${ }^{4}$ In addition, BWID personnel and BWID subcontractor personnel shall comply with applicable triaing requirements contained in federal regulation and applicable DOE Orders and Manuals. These include but are not limited to 29 CFR 1910.120, 29 CFR 1910.1200, DOE Radiological Control Manual, DOE Order 5480.20 and DOE Order 5480.23 (see Attachment 1).

\subsubsection{Health and Safety Plan Addendum}

When the HSP is revised to accurately reflect the current BWID technology demonstration, the project manager shall ensure that the personnel receive the specific training required by the HSP addendum before beginning the technology demonstration. The project manager shall be responsible to prepare:

- Lesson plan for ERP Health and Safety Plan

- Lesson plan for the Health and Safety Plan Addendum.

The HSP training lesson shall be project-specific (intrusive and nonintrusive technology) rather than generic and shall include as a minimum:

1. Technical kno wledge in the following:

- Potential exposures to chemical, biological, and radiological hazards; human responses to these hazards and recognition of those responses; principles of 
toxicology and information about acute and chronic hazards; and health and safety consideration for the BWID technology demonstration.

- Fire explosion hazards (i.e., flammable and combustible liquids, reactive materials).

- General safety hazards such as electrical hazards, powered equipment hazards, walking/working surface hazards, hazards associated with hot or cold temperature extremes, etc.

- The contents of an effective confined space program including, but not limited to, trenches and tank and vault entries.

- Work practices to minimize employee risk from BWID technology demonstration hazards.

- Safe use of engineering controls and equipment, and any new relevant technology demonstration.

- If required, an overview and demonstration of air sampling and monitoring equipment that may be used during the performance of BWID technology demonstration.

- If required, container-sampling procedures and safeguarding; general drum-and container-handling procedures including special requirements for laboratory waste packs, shock-sensitive wastes, and radioactive wastes.

- Proper use of, and limitation of, equipment used in BWID technology demonstrations.

- Where appropriate and required, procedures for safe and healthful preparation of containers for shipping and transport. 
- Waste minimization goals if BWID technology demonstration will result in the generation of mixed waste, radioactive waste, or hazardous waste.

- Methods of communication, including those used while in personal protective equipment (PPE).

2. Technical skills in the following areas:

- Selection, use, maintenance, and limitation of PPE during the performance of BWID technology demonstration (to comply with 29 CFR 1910.134 requirements).

- Instruction in a decontamination program including personnel, equipment, and hardware. Hands-on training shall include level A, B, and C PPE ensembles and a decontamination line including the don and doff of ensembles to a level commensurate with anticipated job function and responsibilities and to the degree of BWID technology demonstration potential hazards.

Additional requirements may be identified when the nonintrusive technology is developed.

\subsubsection{Determintion of Specific BWID Safety Training}

In general, two methods will be used to determine whether a BWID technology demonstration will require additional training at the RWMC: (a) Safety Review, Analysis and Work Control (EG\&G Idaho, Inc., Safety Manual Section 2) and (b) the Unreviewed Safety Question (USQ) (WMPD 2.13). The latter is performed when the existing RWMC Safety Analysis Report (SAR) does not cover the training requirements to conduct BWID demonstrations. The concept of an "unreviewed safety question" was established by BOE to allow contractors to make physical and procedural changes and to conduct tests or experiments without prior DOE approval, as long as these changes do not explicitly or implicitly affect the authorization basis of the facility or result in a technical safety requirement change. 


\subsubsection{Mandatory Training Requirements}

Training for facility access is based primarily on Codes of Federal Regulations and Department of Energy orders. EG\&G Idaho company requirements, as well as department and facility standards are limited to only those necessary for unescorted access to the facility. These requirements are further identified in the following matrix (Table 1 and 2). 


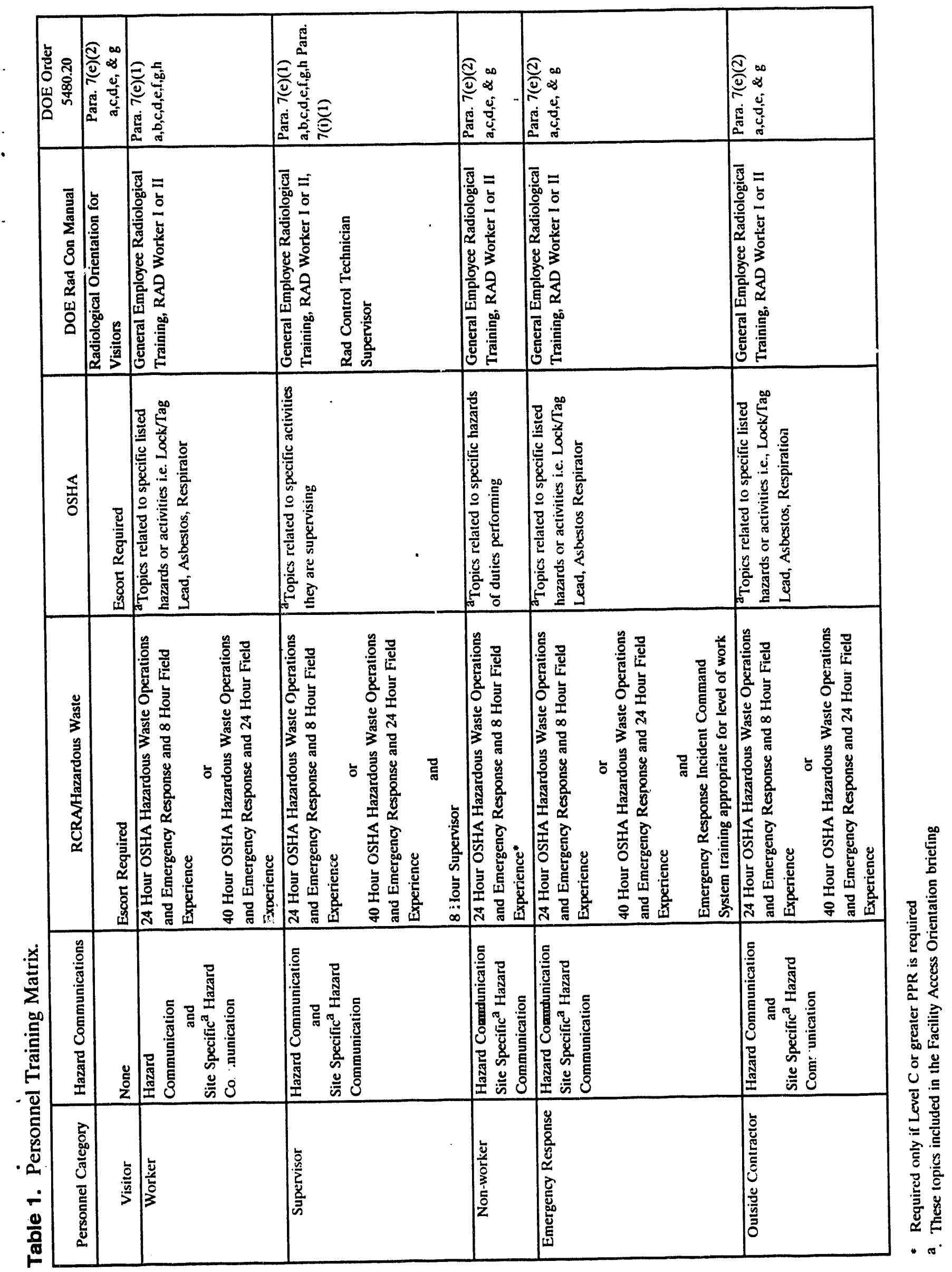


Table 2. 29 CFR 1910.120 - Hazardous 'Naste Operations Training Requirements.

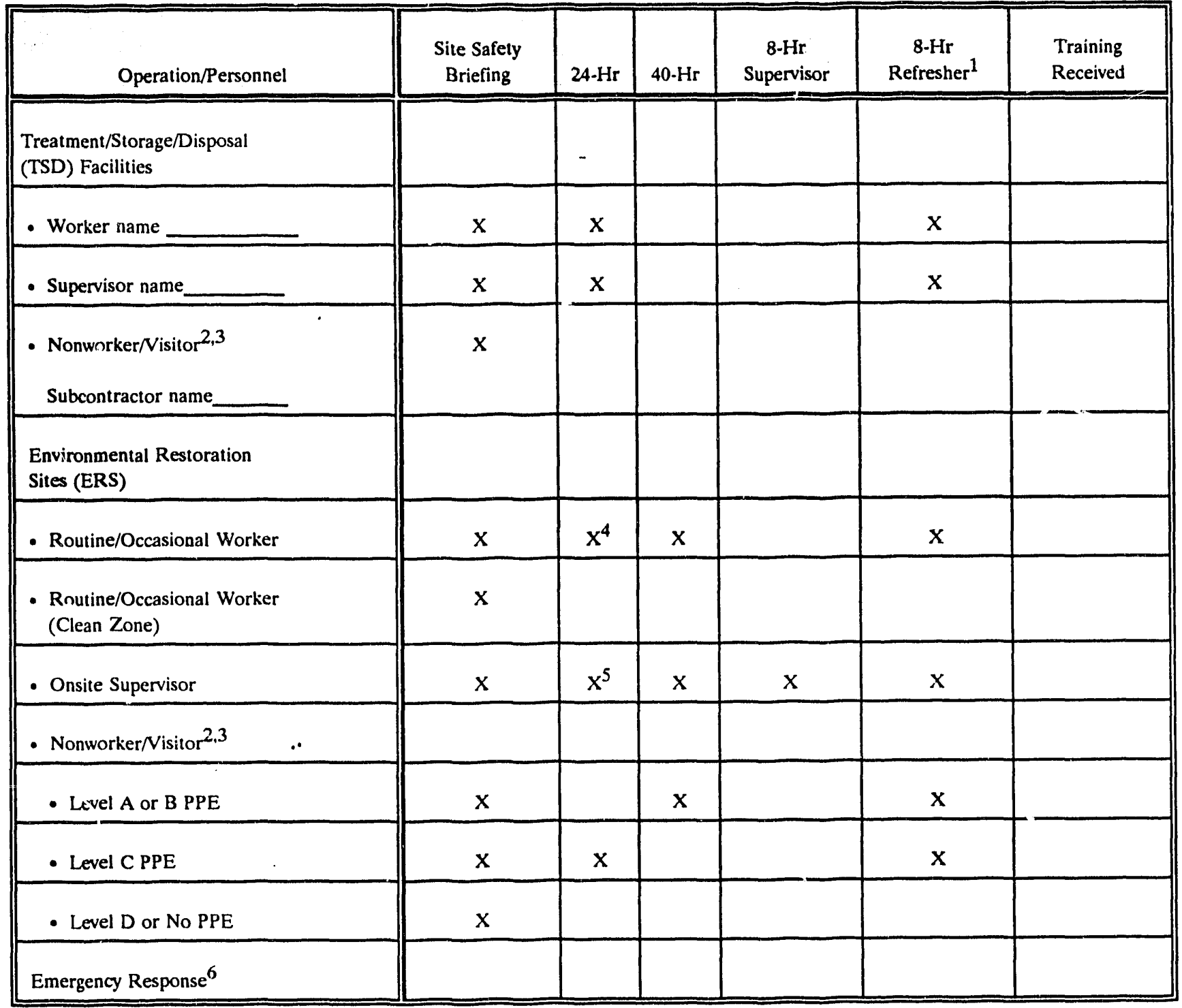

1. Annual requirement; however, personnel not receiving refresher training within three years of initial training of last refresher course (at a minimum) should repeat the initial course.

2. All visitors should be issued PPE and instructed on the use of required personal protective equipment, receive a site-specific safety briefing, and be escorted by trained personnel.

3. Nonworkers are DOE employees and DOE contractors not directly involved with hazardous waste or other TSD/ERS operation (e.g., management, audit, and oversight personnel). Visitors include those covered and not covered by OSHA. Visitors not covered by OSHA who are granted an EH-1 waiver from training requirements should comply with footnote 2 requirements above.

4. 24-hour training is adequate for these workers only for entry into areas where Level D PPE is ১دfficien' For routine workers, area must also hav - veen monitored and fully characterized.

5. Supervisors of ERS onsite workers who require only the 24-hour course need only take the 24-hour initial and 8-hour supervisor courses.

6. Training requirements for emergency response programs are described in OSHA 29 CFR 1910.120(p)(8) and (q). 


\section{TRAINING IMPLEMENTATION STRUCTURE}

\subsection{Interaction}

In its site-specific training efforts, the T\&EA staff at the RWMC will encourage the participation of BWID personnel and BWID subcontractor personnel in the planning and implementation of the training requirements at the RWMC. The section describes the activities that T\&EA staff and BWID will take to achieve this goal.

\subsection{Training Site Preparation}

\subsubsection{Preliminary Documentation}

This document shall be distributed to technology personnel. Training forms (see Attachment 1) will also be distributed and specific briefing iegarding training and additional information pertaining to training requirements will be held. The BWID wil also oversee, coordinate, and evaluate the effectiveness of interface activities between RWMC, BWID, and BWID Subcontractors associated with this training plan.

\subsubsection{Training Forms}

The training forms shall be completed and signed by BWID personnel or BWID subcontractor personnel and their immediate management to formalize the training process requirements.

\subsubsection{Training Form Verification}

The T\&FA staff and the BWID representative at the RWMC will review the training forms and evaluate appropriateness based on:

- Level of training received. 
- Consistency with existing general EG\&G Idaho training requirements and RWMC sitespecific training requirements.

- Consistency with existing interface agreement and laws and regulations (OSHA worker safety training and emergency response requirements).

- The extent $\cap$ the BWID technology demonstration.

If required, a more detailed mechanism shall be developed to fulfill the BWID external training requirements. Based on factors involved at a specific technology demonstration, one or more of the approaches may be employed.

- Include a training section in the facility interface agreement.

- Evaluate pending BWID technology demonstration (HSP, RWMC SAR, etc.) to determine the adequacy of present documents. 


\section{COST AND SCHEDULE}

\subsection{Cost}

The BWID shall provide a dotailed cost breakdown for the RWMC T\&EA staff services. Services shall be negotiated by BWID on a case-by-case basis according to the provisions of the facility interface agreement.

A breakdown of the general technology demonstration costs shall be prepared for subsequent negotiation; the breakdown must be equivalent to or similar to the following sample.

- General administrative costs

- RWMC T\&EA staff costs

- Material costs

- Other costs.

\subsection{Schedule}

The DCAM shall prepare and submit an annual schedule for the entire BWID technology demonstration including mobilization, performance of the technology demonstration, and demobilization. The schedule shall provide milestones and be sequenced to allow a consistent flow of activities to prevent interferences. 


\section{QUALITY ASSURANCE PROGRAM}

At least once during the performance of the BWID technology demonstration, the DCAM or designated alternate and the trainer shall conduci a training requirements quality control audit, which shall be in writing. Training modifications to address deficiencies, if any, shall be documented, approved, and implemented by the DCAM. The audit results shall be maintained by the training entity and the DCAM. Guidelines are provided for the establishment and execution of the QA training program to be used during the performance of technology demonstration. The purpose of the QA training program is to ensure proper training to protect workers, the public, and the environment.

A quality assurance plan shall address at least the following considerations.

\subsection{Confirmation of Adequate Training}

Adequacy and appropriateness of the training requirements conterts and support documents shall be confirmed by the trainer and the DCAM belore start of technology demonstrations. Training criteria shall include:

- Duration of training, course content, and checklist(s).

- Specific training requirements applicable to the various technology demonstration personnel.

- Appropriate technical input, outside review and evaluation.

- Hands-on demonstration and instruction methods applicable to BWID terhnology demonstrations.

- Adequate monitoring of student safety, progress, and performance while on training and during the performance of BWID technology demonstration. 


\subsection{Training Management and Verification During Technology Demonstration}

The training personnel or training subcontractor personnel responsible for implementing plans required by Section 4 of this TRRP shall provide objective evidence of the following:

- $\quad$ Leadership in ensuring quality of worker health and safety training

- Competency to meet the demands of delivering high-quality occupational health and safety training to hazardous waste workers

- That the training organizational structure suits the needs of the BWID training requirements

- $\quad$ Adequate time committed to the BWID training requirements

- Adequate organization and appropriate resources assigned to ensure appropriate training.

\subsection{Quality Control and Evaluation}

Evaluation of training quality assurance shall be conducted by the BWID subcontractor in the form of QA audits and independent management assessment of technology demonstration activities. Results of these audits and assessments shall be evaluated to assess completeness, adequacy, and effectiveness of the implementation of the planning and supporting documents. This evaluation shall be documented and reported to the DCAM, project manager, and RWMC trainer. The RWMC T\&EA staff will, if required, $\mathrm{p}$.rform independent safety and quality oversight. The results of this evaluation shall also be reviewed by the responsible DCAM. Follow-up or corrective action shall be taken where indicated by the evaluation report. 


\subsection{Document and Configuration Control}

The BWID or RWMC T\&EA staff shall be responsible for controlling the issuing, distributing, and changing of technology demonstration's training requirements, including detailed operational procedures, and checklist concerning training requirements.

Training Records will be retained at the RWMC during the performance of the BWID project. At the conclusion of the project the training records will be transferred to BWID project file. 


\section{REFERENCES}

1. L. R. Watson, Interface Agreement Between the Radioactive Waste Management Complex Building Manager and Buried Waste Integrated Demonstration-Integrated Demonstration Coordinator.

2. EG\&G Idaho, Inc., EG\&G Idaho Safety Manual, "Occupational Exposure Requirements."

3. PD-W-79-024 - Operational Safety Requirements for the Radioactive Waste Management Complex.

4. D. L. Smith and S. M. Hailey, Health and Safety Plan for Operations Perforned for the Environmental Restoration Program. 


\section{APPENDIX A}

BURIED WASTE INTEGRATED DEMONSTRATION

TRAINING CHECKLIST 
Radioactive Waste Management Complex

Stored Waste Examination Pilot Plant

BWID Traiñing Checklist

Name:

S Number:

Date Issued:

Date Completed:

BWID Project:

BWID Project \#

BWID Program Manager

M/S

\section{General Instructions}

This checklist is intended for those EG\&G and subcontractor personnel who will be participating in Buried Waste Integration Demonstration (BWID) projects performed at the RWMC. This checklist is designed to accompany information presented during RWMC Access Orientation. The checklist may be issued during the Access Orientation Course or may be given directly to the employee by the BWID Program Manager.

The individual trainee shall demonstrate, by oral checkout or by written examination, a satisfactory knowledge of all items listed below. Items requiring signoff verification shall be signed and dated by the appropriate project manager or the RWMC Training Coordinator when the individual has satisfactorily completed the specified requirements. The BWID program manager, RWMC Training Coordinator or other specified individual as indicated on the checklist will review and verify completion of each section of this checklist. The BWID Program Manager shall review and verify completion of the checklist.

This checklist, when completed, shall be retained by the RWMC Training Coordinator in the individual's training file for the duration of the project. Files will be forwarded to the BWID office at completion of the project.

On a case basis, specific items may be marked as deleted or non-applicable (N/A). The approval for deletion or non-applicability must be approved by the BWID Program Manager and so iiflicated by initials and date on each item marked. Items may be added to the checklist at the discretion of the BWID program manager and the RWMC Training Coordinator.

This checklist should be completed prior to the start of the designated BWID project. If the checklist cannot be completed within this time period a written request with appropriate justification for extension must be forwarded to the BWID Program Manager with a copy to the RWMC Training Coordinator. Extension policies will be followed as outlined in the in Waste Management Department Training Program Manual Section 2.4.

\section{Acronyms}

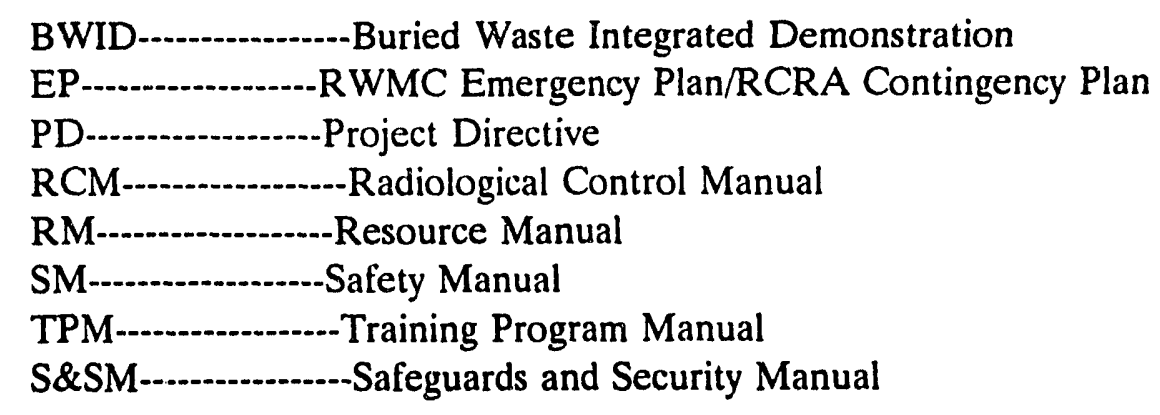


I. Access Orientation

Access Orientation is a formal classroom training program that may be presented in its entirety or broken into modules and presented separately. Signatures indicating completion of the modules listed below will be provided by the classroom instructor and dated for each module. Individual line items that are not applicable shall be marked NA in the signature column.

Module 1 Introductions and General Description of Facility

1.1 General Facility Description

Orientation Video

Facility Map

RWMC Work Process

SWEPP

TSA

SDA

Cleanup Projects

Names of personnel responsible for these processes

Review of radiation zones and hazardous waste areas

1.2 Familiarization with entry dosimetry

1.3 RWMC Transportation

Module 2 Radiological Health and Safety

2.1 Personnel and Vehicle Access Control (PD-RS-6.8)

\subsection{Radiation Safety Briefing}

2.3 Monitoring

2.4 Instrumentation and Alarms

2.5 Release Tags

Module 3 Industrial Safety and Hygiene

3.1 RWMC Hazard Briefing

3.2 Industrial Safety Briefing

3.3 RCRA Briefing

Module 4 Emergency Preparedness

4.1 Emergency Response Briefing 
4.2 Facility Alarms

4.3 Emergency Procedures

4.4 ID Card and Health and Safety Permit Verification

4.5 RWMC Security Awareness Briefing

Access Orientation Final Exam:

Exam Score

Section I Compieted:

Training Coordinator Signature

Date

II. Job Specific

The BWID Program Manager shall designate the following required Safety Training as applicable to the individuals job position and physical condition. This training may be waived if documentation can be produced showing previous completion of training. Procedures outlined in the Training Requirements and Responsibilities for the Performance of the Buried Waste Integrated Demonstration at the Radioactive Waste Management Complex document apply. The RWMC Records Administrator or the BWID Program Manager shall schedule the training if required. If, for any reason the initial scheduled sessions are not met, it is the responsibility of the BWID Program Manager to submit the new date for training to the Records Administrator.

\section{Training Course}

A. Hazard Communication

Hazard Communication Refresher

OSHA Hazardous Waste Operations and Emergency Response (40. Hour)

OSHA Hazardous Waste Operations and Emergency Response (8 Hour)

OSHA Hazardous Waste Operations and Emergency Response (Supervisor)

OSHA Hazardous Waste Operations and Emergency Response (24 Hour)
Course Number N/A Required

TS-100

TS-100R

TS-205

TS-205R

TS-206

TS-207
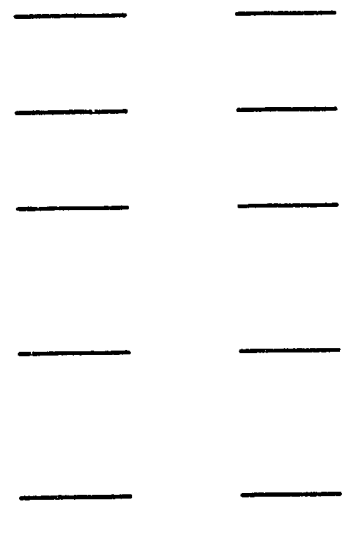
B. Radiation Worker

Rad Worker Refresher

Non-Rad Worker

C. Hazardous Material Carrier

Hazardous Material Shipper

Hazardous Material Shipper

Requalification

D. Medic First Aid

(required for brigade)

Medic First Aid Refresher

E. Respirator

Respirator refresher

Medical Evaluation
TS-501

TS-501R

TS-509

HZ 100

HZ 110

HZ 111

TS-701

TS-701R

TS-801

TS-802

1. Initial Specific Criteria
a. RADWORKER
b. Hazardous Waste Operator
c. DOT Driver
d. Respirator
e. Other

2. Routine Periodic
a. RADWORKER
b. Incidental Forklift Operator
c. Hazardous Waste Operator
d. Respirator
e. Other

3. Company Physical Only

"Indicates type of exam on medical exam form

$\underline{\text { Radiological Controls Engineer Evaluation }}$

1. Whole Body Count

2. Bioassay
a. Lung Count
b. Fecal Analysis
c. Urinalysis
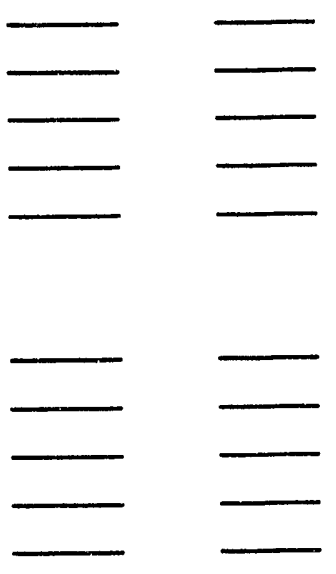
Section II Completed:

Manager's Signature

Date

Section III: BWID Programs

The BWID Program Manager or designated alternate will conduct briefings or obtain appropriate course materials. BWID Program Manager or designated alternate will supervise progress toward completion and will verify satisfactory completion of materials.

\section{Signature \\ Date}

1. Health and Safety Plan

2. Accountability

3. Conduct of Operations

4. Lockout/Tagout

5. Right to Know

6. Required Reading

7. Construction Standards

8. General Environmental Control

9. Confined Space Entry

Section III Completed:

BWID Manager's Signature

Date

Section IV: Facility Documentation Requirements

Signature Date

1. Permanent TLD Application Complete (RC Admin)

2. Card Reader Application Complete (Landlord Rep.)

3. Individual Training Record 
Section IV Completed:

$\overline{\text { RMWC Technical Programs Manager's Signature }}$

Date

Checklist Completion:

Employee has completed all sections of this checklist satisfactorily.

Employee's Signature

Manager's Signature
Date

Date

Original completed checklist placed in employee's training record 


\section{APPENDIX B}

BURIED WASTE INTEGRATED DEMONSTRATION (BWID)

TRAINING PLAN MATRIX 


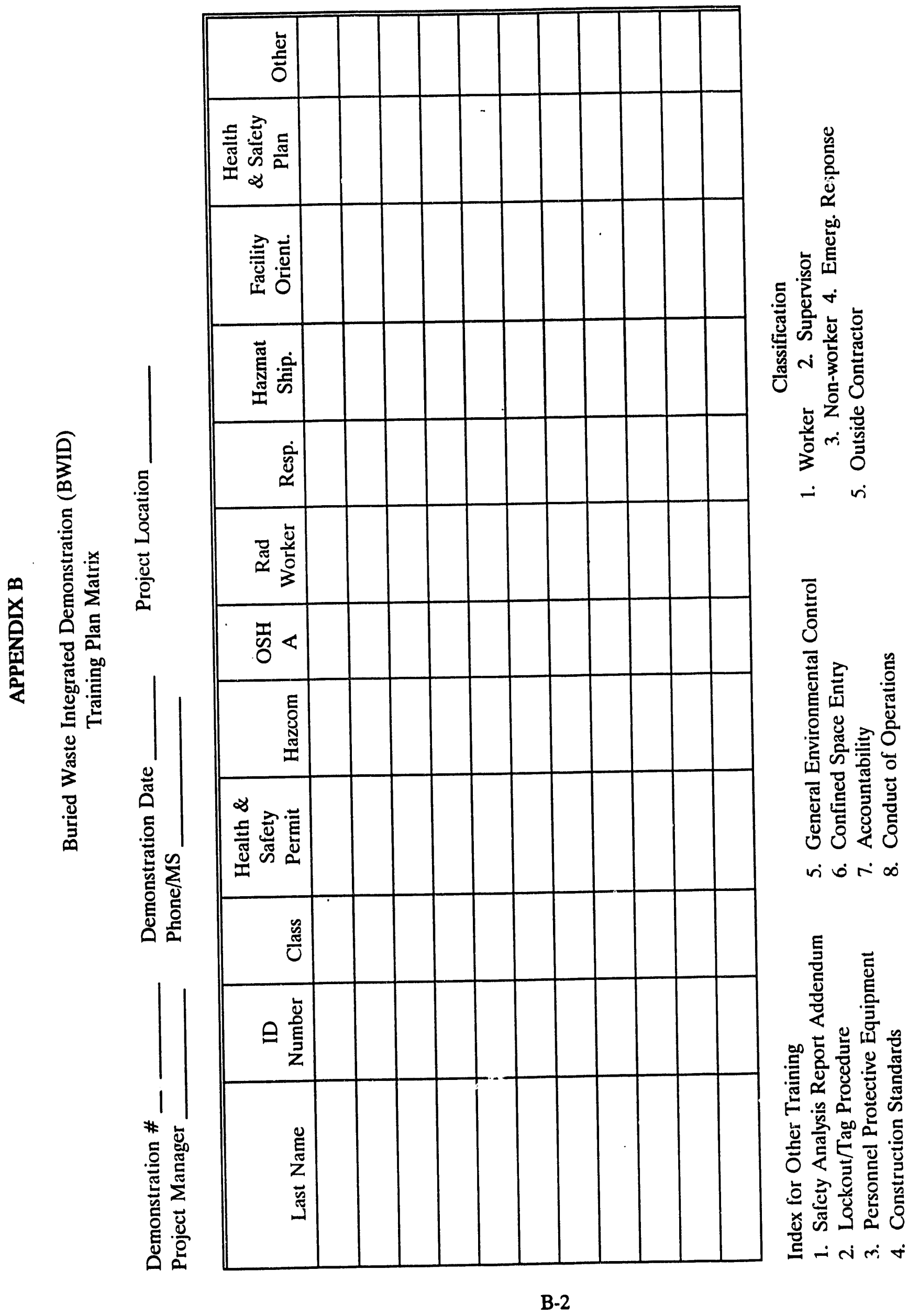



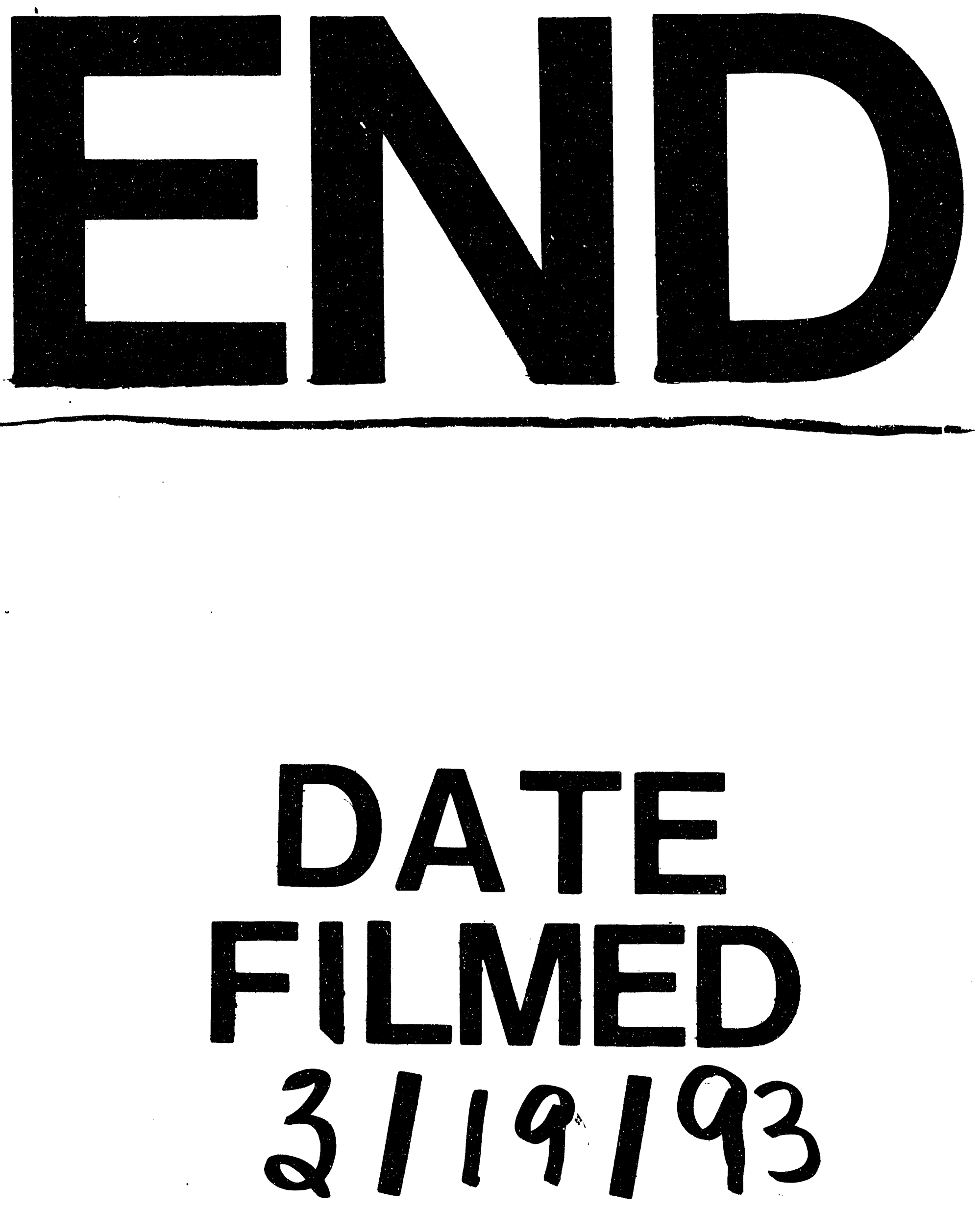
